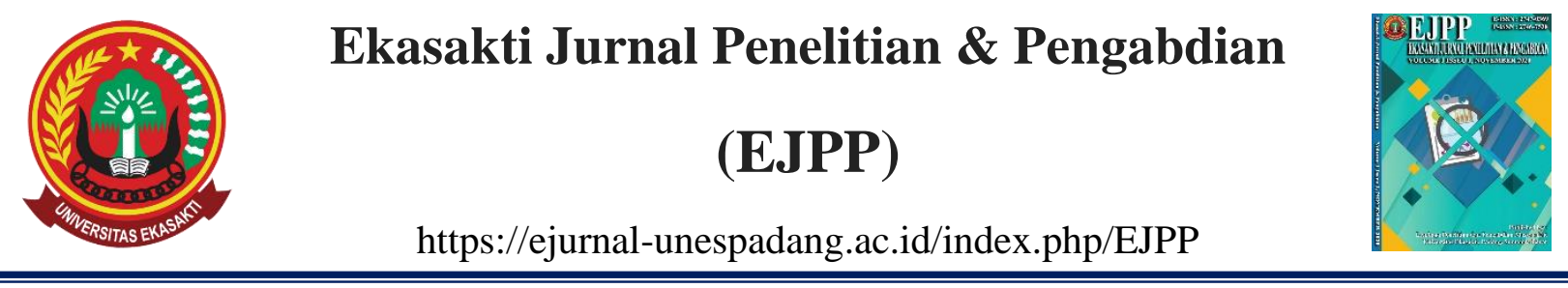

\title{
PEMBERLAKUAN ATURAN NEW NORMAL DAN IMPLEMENTASINYA DI KELURAHAN PASIE NAN TIGO KOTA PADANG
}

\author{
Jaenam $^{1}$, dan Budi Juliardi \\ 1) Program Studi PPKn, STKIP PGRI Sumatera Barat. \\ Email: Jaenamjae75@gmail.com \\ 2) Program Studi PPKn STKIP PGRI Sumatera Barat. \\ Email: rizhan_budi@yahoo.com
}

INFO ARTIKEL

Received : 28/03/2021

Revised : 15/04/2021

Publish : :01/05/2021

Kata Kunci:

Covid-19, New Normal, Perda.

\begin{abstract}
ABSTRAK
Pengabdian kepada masyarakat tentang sosialisasi mengenai pemberlakuan aturan new normal dan implementasinya di Kelurahan Pasie nan Tigo Kota Padang dilatarbelakangi dengan adanya kebijakan pemerintah tentang Peraturan Daerah Provinsi Sumatera Barat No. 6 tahun 2020 tentang Adaptasi kebiasaan baru dalam pencegahan dan pengendalian corona virus disease 2019. Adapun yang menjadi permasalahan disini adalah bahwa masyarakat Pasie Nan Tigo masih banyak yang belum memahami mengenai bagaimana mengimplementasikan aturan new normal serta cara menjaga kesehatan selama masa new normal untuk mencegah penyebaran virus covid 19. Metode kegiatan pengabdian kepada masyarakat dilakukan dengan melalui tahapan 1) analisis kebutuhan, 2) rencana kerja, 3) pelaksanaan kegiatan, 4) evaluasi. Hasil Kegiatan pengabdian kepada masyarakat dengan target sasaran adalah masyarakat dengan cara penyebaran pamphlet yang disebarkan kepada warga masyarakat. Pamphlet juga disebarkan pada warga RT 001/RW/004 Kelurahan Pasie Nan Tigo yang berjumlah lebih kurang 50 kepala keluarga mendapat respon positif masyarakat dan pemahaman masyarakat cukup baik.
\end{abstract}

Keywords:
Covid-19, New Normal,
Perda.

Keywords: Perda.

\begin{abstract}
Community service regarding the socialization of the implementation of the new normal rules and their implementation in the Pasie nan Tigo Village, Padang City is motivated by the government's policy on the Regional Regulation of the Province of West Sumatra No. 6 of 2020 concerning Adaptation of new habits in the prevention and control of corona virus disease 2019. The problem here is that there are still many Pasie Nan Tigo people who do not understand how to implement the new normal rules and how to maintain health during the new normal period to prevent the spread of the virus. covid 19. The method of community service activities is carried out through stages 1) needs analysis, 2) work plan, 3) activity implementation, 4) evaluation. The results of community service activities with the target community being the distribution of pamphlets distributed to the community. Pamphlets were also distributed to residents of RT 001/RW/004, Pasie Nan Tigo Village, which amounted to approximately 50 families.
\end{abstract}

DOI: https://doi.org/10.31933/ejpp.v1i2.321 


\section{PENDAHULUAN}

Berdasarkan analisis situasi sampai saat ini wabah virus corona (covid-19) masih terus menyebar. Berbagai upaya terus dilakukan untuk mencegah penyebarab semakin meluas, salah satunya dengan menerapkan aturan social distancing psysical distanching serta penerapan Pembatasan Sosial Berskala Besar (PSBB). Dengan diberlakukanya PSBB, maka komunikasi langsung antar individu menjadi terbatas.

Setelah pemberlakuan PSBB di Indonesia, maka dimulai kehidupan baru yang selanjutnya disebut dengan masa new normal. Mentri Dalam Negeri (Mendagri) Tito Karnavian mengeluarkan aturan new normal dalam menghadapi virus corona atau covid-19 yang tertuang dalam Keputusan Menteri Dalam Negari (Kepmendagri) No.440-830 Tahun 2020 tentang pedoman tatanan normal baru bagi pemerintah daerah dan Aparatur Sipil Negara (ASN) dilingkungan kementrian dalam negeri.

Pada prinsipnya memang tidak selamanya masyarakat hidup dalam masa karantina, Indonesia harus memulai aktifitas diberbagai sector dengan menerapkan secara ketat protokol kesehatan agar terjadi harmoni dan kewaspadaan dalam pencegahan dan penangan covid-19. faktanya, sudah ada beberapa Negara yang mulai pulih dari ancaman virus ini, walaupun sejumlah ahli memprediksi pandemic covid-19 bisa berlangsung lama. Dalam kaitan kebijakan pemerindah daerah sebelum menerapkan normal baru, Pemda harus melaksanakan pemetaan penyebaran covid-19. Pemetaan dilakukan dengan melibatkan pemengku kepentingan sehingga Pemda mempunyai basis data yang kuat tentang persoalan ini.hasil pemetaan dibagi dalam 3 kluster.

1. daerah yang kondisi epidemologisnya menurun/rendah yang disebut zona hujai apabila hasil pemetaan memperoleh nilai 100;

2. daerah yang kondisi epidemologisnya mendatar/sedang yang disebut zona kuning, apabila hasis pemetaan memperoleh nilai 80-95;

3. daerah yang kondisi epidemologisnya meningkat atau tinggi yang disebut zona merah, apabila hasil pemetaan memperoleh nilai 60-75.

Pedoman yang dikeluarkan mencakup semua bidang seperti sekolah. Tempat kerja, ruang publik hingga pusat keramaain seperti pasar, mall dan pertokoan.

Berdasarkan kondisi diatas, maka kondisi new normal biasa diterapkan diseluruh wilayah di Indonesia dengan catatan bahwa pemerintah daerah masing-masing harus mampu untuk tetap menjaga agar covid-19 tidak semakin menyebar. Dengan demikian, pemahaman masyarakat mengenai implementasi aturan new normal serta kesadaran masyarakat akan pentingnya mematuhi aturan kesehatan pada masa new normal tetap harus dijaga agar covid-19 tidak semakin menyebar. Untuk itu pengebdian masyarakat ini dilakukan dengan tujuan untuk meningkatkan kesadaran masyarakat agar mematuhi protocol kesehatan selama masa new normal.

\section{a. Batasan Kegiatan}

Berdasarkan uraian pada latar belakan yang telah dikemukakan, maka kegiatan ini perlu dibatasi sebagai berikut:

1) Kegiatan dilaksanakan pada kelurahan Pasir Nan Tigo namun dikhususkan pada RT.003/ RW. IV; 
2) Kegistsn ini dilaksanakan selama 1 bulan mulai dari persiapan, pelaksanaan, dan penulisan laporan kegiatan.

b. Manfaat Pelaksanaan

Secara teoritis, diharapkan dengan kegiatan pengabdian ini warga masyarakat Kelurahan Pasir Nan Tigo khususnya warga RT 003/RW IV memahami adanya aturan baru normal (New Normal) yang dikeluarkan oleh Pemerintah Daerah. Sedangkan secara praktis diharapkam masyarakat mampu mengaplikasikan dan menjadi warganegara yang taat atas aturan yang berlaku dalam masyarakat.

\section{METODE PENELITIAN}

Metode pelaksanaan kegiatan ini dilakukan untuk memberikan solusi dalam rangka mengatasi permasalahan mitra. Pendekatan yang digunakan adalah pendekatan yang bersifat "bottom up", dimana perencanaan tindakan diupayakan menjawab permasalahan dan kebutuhan mitra dan dilakukan secara intensif dan partisipatif. Tahapan yang dilakukan secara umum adalah sebagai berikut:

1. Analisis kebutuhan, Menganalisis kebutuhan mitra untuk mencari solusi dari permasalahan;

2. Rencana kerja, adalah setelah menganalisis kebutuhan mitra, pelaksana membuat rencana kerja atau kegiatan yang akan diterapkan. Rencana kerja meliputi: a) persiapan kegiatan, b) pelaksanaan kegiatan, c) monitoring dan evaluasi kegiatan;

3. Pelaksanaan kegiatan, meliputi kegiatan pelaksanaan pemberian pelatihan dan workshop dilokasi mitra yang sesuai rencana kerja yang disusun;

4. Evaluasi, untuk semua program kegiuatan dan evaluasi sesuai dengan target luaran.

\section{HASIL DAN PEMBAHASAN}

\section{Pelaksanaan Kegiatan}

Kegiatan pengabdian kepada masyarakat yang dilaksanakan selama satu bulan, yang dimulai tanggal 4 juni 2020 hingga tanggal 30 juni 2020. Pelaksanaan kegiatan tidak dilakukan dengan mengumpulkan massa karena suasana masih dalam pandemic covid-19. Sosialisasi yang biasanya dilakukan dengan pengumpulan massa diganti dengan cara menyebarkan pamphlet yang sesuai dengan materi kegiatan.

Materi yang diberikan adalah memberikan pemahaman kepada masyarakat mengenai pentingnya mematuhi aturan PSBB untuk membentuk karakter taat hokum dalam rangka memutus rantai penyebaran virus covid-19. Tidak bias dipungkiri bahwa virus covid -19 dapat menyebar melalui banyak media, sehingga dibutuhkan kedisiplinan dan ketaatan dari warga masyarakat dalam menjaga diri dan lingkungan untuk bias terhindar dari penularan virus covid -19.

Pamphlet dicetak oleh tim pengabdian pada masyarakat lalu disebarkan secara langsung kepada warga di RT.003/RW IV Kelurahan Pasir Nan Tigo. Tim secara langsung mengunjungi ketua RT, lalu meminta kesediaanya untuk menemani tim dalam membagikan pamphlet secara 
langsung kerumah warga. Terdapat sekitar 50 kepala keluarga yang ada dilikasi kegiatan dan semaunya telah memperoleh pamphlet yang dibagikan. Adapun isi dari pamphlet yang disebarkan adalah:

1. Aturan new normal

New normal adalah perubahan prilaku atau kebiasaan untuk tetap menjalani aktifitas seperti biasa, namun dengan selalu menerapkan protocol kesehatan ditengah pandemic covid-19. Himbauan dari pemerintah ini menganjurkan agar kita bias hidup "berdampingan" dengan virus yang telah menelan ratusan ribu jiwa diseluruh dunia. Sejak pandemic covid-19 muncul, hamper semua orang mengalami kendala untuk menjalani kehidupan normal akibat pembatasan yang perlu dilakukan untuk mencegah penularan virus corona. Namun,dengan usainya pembatasan tersebut,pemerintah menganjurkan kita untuk mulai melakukan kegiatan seperti biasa,tentunya sambil mematuhi protocol pencegahan covid-19.

2. Cara beraktivitas selama new normal

Berikut adalah hal-hal penting yang perlu kamu ketahui untuk menghadapi new normal:

a. Saat harus keluar rumah dan kembali lagi kerumah

Penerapan new normal akan membuat kita lebih longgar untuk keluar rumah. Namun, mengingar pandemic covid-19 masih berlangsung,kita harus tetap manmerapkan langkah pencegahan dasar kapan pun dan dimanapun kita berada. Selain itu, jangan memaksakan diri keluar rumah saat kondisi fisik tidak sehat.bila keperluan sudah selesai,segera kembali ke rumah.sesampainya di rumah langsung lakukan beberapa hal berikut seperti membuka alas kaki sebelum masuk rumah,semprotkan desinfektan pada alas kaki maupun peralatan yang di gunakan, mencuci tangan dengan air dan sabun, lepaskan pakaian yang digunakan dan segera masukan kedalam tempat cucian yang tertutup, mandi dan berganti pakaian bersih sebelum berkumpul dengan keluarga.

b. Sewaktu menggunakan transportasi umum

Bila harus bepergian ke suatu tempat dan menggunakan transportasi umum, ada beberapa hal yang harus di perhatikan selain menerapkan langkah pencegahan dasar. Untuk memudahkan dalam menjaga kebersihan tangan, bawalah selalu hand sanitizer. Jangan menyentuh wajah dan tangan yang belum dibersihkan. Selain itu, pastikan kamu membawa botol minum agar tidak dehidrasi. Selama perjalanan di dalam transportasi umum harus mengurangi interaksi dan menjaga jarak setidaknya 1 meter dengan penumpang lain. Bila hal ini tidak memungkinkan, sebaiknya jangan menggunakan transportasi umum.

c. Selama bekerja di kantor

Di mulainya new normal akan membuat para karyawan kembali bekerja di kantor secara bertahap setelah beberapa bulan bekerja dari rumah. Agar tetap aman dan terhindar dari virus corona di tempat kerja, kamu perlu menerapkan physical 
distancing dalam setiap kegiatan di kantor. Ketika beraktivitas di meja kerja ataupun saat rapat pastikan jarak kursi minimal $1 \mathrm{~m}$. bila ada rekan kerja yang duduk dengan jarak yang kurang dari $1 \mathrm{~m}$ jangan ragu untuk menegur dan mengingatkan agar menjaga jarak. Begitu juga saat makan siang jika sebelumnya makan siang di kantin sementara ini usahakan untuk selalu membawa bekal dari rumah agar tidak perlu ketempat yang ramai untuk membeli makanan. Saat makan siang bersama di kantor pun tetap jaga jarak dengan rekan-rekan sekantor.

d. Ketika berbelanja

Bila harus berbelanja membeli bahan makanan, kemungkinan akan bertemu banyak orang. Selalu terapkan physical distancing. Batasi menyentuh barang barang di toko maupun di tempat umum. Setelah meyentuh barang-barang tersebut jangan menyentuh wajah atau barang-barang pribadi seperti hp, tas, dan barang-barang lainnya sebelum mencuci tangan. Tujuannya adalah mengurangi resiko terkontaminasi virus covid-19. Catat barang barang apa saja yang perlu di beli dan langsung kekasir ketika semua sudah di dapatkan. Hal ini pun berlaku ketika makan di restoran, tentu harus melepaskan masker, pilihlah tempat makan dengan ventilasi yang baik agar ada pertukaran udara di tempat tersebut. Selalu jaga jarak dengan orang lain, termasuk pramusaji, pengunjung lain dan kasir. Sewaktu membayar dunakan metode pembayaran non tunai untuk mencegah kontaminasi. Namun jika tidak memungkinkan pastikan untuk langsung mencuci tangan setelah selesai belanja

e. Warga masyarakat diminta untuk memeatuhi aturan new normal

Sebagai warga Negara yang baik dan masyarakat yang hidup berdampingan dengan masyarakat lain harus mematuhi apapun aturan yang di tetapkan oleh pemerintah, karena pada prinsip nya aturan dibuat untuk kepentingan bersama, termasuk aturan new normal yang sangat berguna untuk memutis mata rantai penyebaran covid-19.

\section{Keberhasilan}

Kegiatan yang dilakukan ini bias dikatakan telah mencapai target yang di tetapkan. Target yang ditetapkan adalah masyarakat Kelurahan Pasir Nan Tigo memiliki kesadaran untuk mematuhi aturan new normal dan melaksanakan berbagai ketentuan yang ditetapkan semasa new normal. Setelah kegiatan dilakukan serta pamplet telah dibagikan kepada masyarakat terlihat masyarakat Kelurahan Pasir Nan Tigo telah mulai mematuhi aturan new normal. Mereka beraktivitas dalam kegiatan sehari hari, akan tetapi mereka menggunakan masker, mencuci tangan setiap selesai beraktivitas, dan lain sebagainya. Demikian juga saat tim membagikan pamphlet warga masyarakat terlihat antusias bertanya ke pada tim mengenai aturan new normal. 


\section{KESIMPULAN}

Kesimpulan yang didapat diambil dalam kegiatan pengabdian kepada masyarakat ini adalah :

1. Terlaksananya sebuah aturan hakekatnya membutuhkan dungan masyarakat secara penuh, namun untuk sampai aturan yang dibuat oleh pemerintah butuh sarana sosislaisai, salah satunya adalah kegiatan pengabdian kepada masyarakat.

2. Terjalinya mitra kerjasama antara masyarakat dengan masyarakat, serta pemerintah dan masyarakat akan mempermudah akses pencapaian aturan yang akan di sampaikan.terutama dalam menjalankan aturan new normal pada masyarakat kelurahan Pasir Nan Tigo.

Berdasarkan masukan dari pihak perangkat RT/RW dan perangkat kelurahan serta masyarakat Pasir Nan Tigo perlu diadakan kegiatan lanjutan berupa program pelatihan/ sosialisasi lainya.

\section{REFERENSI}

Afendi, A.H. (2020). Dampak Pandemi (Covid-19). Jurnal PGSD, 6 (1).39-49).

Fan Y. Zhao.K, Shi, Zhou P (march 2019) “Bat Coronaviruses In China”.11(3).210

Nuraini, R. (2020, Maret 2). Kasus Covid-19 Pertama, Masyarakat Jangan Panik. Diambil kembali dari indonesia.go.id: https://indonesia.go.id/narasi/indonesia-dalamangka/ekonomi/kasus-covid-19-pertama-masyarakat-jangan-panik.

Provinsi Sumatera Barat. (2020). Peraturan Daerah No 6 Tahun 2020 tentang Adaptasi Kebiasaan Baru Dalam Mencegah Dan Pengendalian Corona Virus Disease 2019

Indonesia. (2020). (Kepmendagri) No.440-830 Tahun 2020 tentang pedoman tatanan normal baru bagi pemerintah daerah dan Aparatur Sipil Negara (ASN) dilingkungan kementrian dalam negeri.

Pedoman Penelitian dan Pengabdian Pada Masyarakat STKIP PGRI Sumatera Barat 2018. 